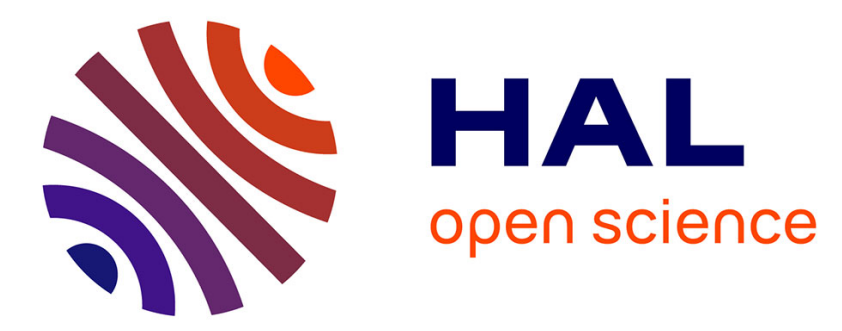

\title{
DNA grafting and arrangement on oxide surfaces for self-assembly of $\mathrm{Al}$ and $\mathrm{CuO}$ nanoparticles
}

Théo Calais, David Bourrier, Aurélien Bancaud, Yves J. Chabal, Alain Estève, Carole Rossi

\section{- To cite this version:}

Théo Calais, David Bourrier, Aurélien Bancaud, Yves J. Chabal, Alain Estève, et al.. DNA grafting and arrangement on oxide surfaces for self-assembly of $\mathrm{Al}$ and $\mathrm{CuO}$ nanoparticles. Langmuir, 2017, 33 (43), pp.12193-12203. 10.1021/acs.langmuir.7b02159 . hal-01613194

\author{
HAL Id: hal-01613194 \\ https://hal.laas.fr/hal-01613194
}

Submitted on 9 Oct 2017

HAL is a multi-disciplinary open access archive for the deposit and dissemination of scientific research documents, whether they are published or not. The documents may come from teaching and research institutions in France or abroad, or from public or private research centers.
L'archive ouverte pluridisciplinaire HAL, est destinée au dépôt et à la diffusion de documents scientifiques de niveau recherche, publiés ou non, émanant des établissements d'enseignement et de recherche français ou étrangers, des laboratoires publics ou privés. 


\title{
DNA grafting and arrangement on oxide surfaces for self-assembly of $\mathrm{Al}$ and $\mathrm{CuO}$ nanoparticles
}

\author{
Théo Calais $^{\dagger}$, David Bourrier ${ }^{\dagger}$, Aurélien Bancaud $^{\dagger}$, Yves Chabal ${ }^{\Psi}$, Alain Estève ${ }^{\dagger}$, Carole Rossi ${ }^{\dagger}$ \\ ${ }^{\dagger}$ University of Toulouse, LAAS-CNRS,7 Avenue du colonel Roche, F-31077 Toulouse, \\ France \\ ${ }^{\Psi}$ Department of Materials Science and Engineering, The University of Texas at Dallas, \\ Richardson, Texas 75080, United States
}

\begin{abstract}
DNA-directed assembly of nano-objects as a means to manufacture advanced nanomaterial architectures has been the subject of many studies. However, most applications have dealt with noble metals as there are fundamental difficulties to work with other materials. In this work, we propose a generic and systematic approach for functionalizing and characterizing oxide surfaces with single-stranded DNA oligonucleotides. This protocol is applied to aluminum and copper oxide nanoparticles due to their great interest for the fabrication of highly energetic heterogeneous nanocomposites. The surface densities of streptavidin and biotinylated DNA oligonucleotides are precisely quantified combining atomic absorption spectroscopy with conventional dynamic light scattering and fluorimetry, and maximized to provide a basis for understanding the grafting mechanism. First, the streptavidin coverage is consistently below $20 \%$ of the total surface for both nanoparticles. Second, direct and unspecific grafting of DNA single strands onto $\mathrm{Al}$ and $\mathrm{CuO}$ nanoparticles largely dominates the overall functionalization process:
\end{abstract}


$\sim 95 \%$ and $90 \%$ of all grafted DNA strands are chemisorbed on the $\mathrm{CuO}$ and $\mathrm{Al}$ nanoparticle surfaces respectively. Measurements of hybridization efficiency indicate that only $\sim 5$ and $\sim 10 \%$ of single-stranded oligonucleotides grafted onto the $\mathrm{CuO}$ and $\mathrm{Al}$ surfaces are involved in the hybridization process, corresponding precisely to the streptavidin coverage, as evidenced by the occupancy of 0.9 and 1.2 oligonucleotides per protein. The hybridization efficiency of singlestranded oligonucleotides chemisorbed on $\mathrm{CuO}$ and $\mathrm{Al}$ without streptavidin coating decreases to only $\sim 2 \%$, justifying the use of streptavidin despite of its poor surface occupancy. Finally, the structure of directly-chemisorbed DNA strands onto oxide surfaces is examined and discussed.

KEYWORDS: Colloids, DNA Self-assembly, Streptavidin, Al nanoparticle, $\mathrm{CuO}$ nanoparticle, loading

\section{INTRODUCTION}

Over the last two decades, the use of DNA has become a mainstream approach for the nanoscale organization of nanoparticles. ${ }^{1,2}$ One such approach consists of directing the formation of wellcontrolled 2-D or 3-D architectures based on colloids of interest using DNA hybridization as a molecular binder. ${ }^{3-7}$ Since the seminal work by Mirkin in the 90 s on gold nanoparticles, many nanoparticle self-assembly processes have been reported for applications in electronics and devices for biodiagnostics, ${ }^{8-11}$ therapeutic agents, ${ }^{12,13}$ plasmon-enhanced spectroscopy,${ }^{14-18}$ magneto-optical sensors, ${ }^{19}$ and catalysis. ${ }^{20}$ Gold or silver nanoparticles are generally used for all these applications, taking advantage of the well-known and controlled reaction between thiol and metal surfaces. ${ }^{21-23}$ An alternative method, using the antigen/antibody interaction, has been reported to immobilize DNA strands on surfaces, notably oxide surfaces, ${ }^{24-28}$ extending the possible applications of organized and controlled heterogeneous structures of nanoparticles. 
In particular, one possible and new application for the DNA nanotechnologies is the synthesis of highly energetic heterogeneous materials, i.e. containing two or more components which can react spontaneously together to deliver energy (heat). Indeed, the association of strong reducer such as aluminum with an oxidizer (in theory any metal oxide) enables an energetic material to deliver a high amount of energy under an external stimulus. ${ }^{29}$ The properties of these materials, called nanothermites, are highly dependent on the size of components and their distribution in the composite. ${ }^{30}$ The use of nanoparticles allows for a significant improvement of energetic properties but there remain important issues to control the mixing of nanoparticles at the nanoscale. In this context, the use of DNA self-assembly shows great potential for the synthesis of a new kind of nanothermites, with exquisite control of the contact surfaces between oxidizer and reducer, thereby enabling the optimization and control of energetic performances.

Preliminary work has recently demonstrated the potential of DNA to increase the energetic performances of self-assembled $\mathrm{Al}$ and $\mathrm{CuO}$ nanoparticles. ${ }^{28} \mathrm{In}$ this study, the assembly was based on the direct hybridization of two complementary DNA oligonucleotides grafted by thiol and biotin functions on $\mathrm{CuO}$ and neutravidin-modified $\mathrm{Al}$ nanoparticles, respectively. In this natural state, $\mathrm{Al}$ nanoparticles are covered by a 3-5 nm-thick alumina layer that protects the $\mathrm{Al}$ core from further oxidation. ${ }^{29} \mathrm{This}_{2} \mathrm{Al}_{2} \mathrm{O}_{3}$ layer directly interacts with DNA, while the aluminum core remains the combustible part of the nanothermite reaction. To stress this fact, $\mathrm{Al}$ nanoparticles will be described as $\mathrm{Al} @ \mathrm{Al}_{2} \mathrm{O}_{3}$ in the rest of this article. Although self-assembly has been demonstrated, the optimal functionalization process and assembly conditions have not yet been determined. Notably, quantification of streptavidin or oligonucleotides binding and DNA hybridization efficiency have never been evaluated for these oxide surfaces. In order to improve the final heterogeneous structure of self-organized $\mathrm{Al}$ and $\mathrm{CuO}$ nanoparticles, it is 
essential to (i) understand the physico-chemical interactions between DNA and oxide surfaces involved in this system, (ii) control the grafting of DNA oligonucleotides on nanoparticles by quantifying and measuring the amount and specificity of DNA, (iii) control the environment parameters such as the chemical parameters (salt and surfactant concentrations), physical parameters (incubation time, sonication), or the choice of sticky-end sequences during the selfassembly.

We previously demonstrated the existence of strong chemical interactions between thymidine $5^{\prime}$ monophosphate (one base of DNA) and $\mathrm{Al}_{2} \mathrm{O}_{3}$ surface. ${ }^{31}$ Numerous chemical bonds between the oxide and the nucleotide were detected not only via the phosphate backbone, as had previously been reported for several metal oxides $\left(\mathrm{Fe}_{3} \mathrm{O}_{4}, \mathrm{CeO}_{2}, \mathrm{TiO}_{2}\right),{ }^{10,32,33}$ but also through the base and its carbonyls functions. These results justified the strategy used to specifically graft DNA onto $\mathrm{Al} @ \mathrm{Al}_{2} \mathrm{O}_{3}$ nanoparticles based on the biotin-streptavidin interaction, as sketched on Figure 1. This strategy was applied to two types of nanoparticles to demonstrate the generic methodology. In our second work, we showed that the DNA "sticky-end" sequence has a strong effect on the efficiency of strand hybridization involved in the self-assembly process, demonstrating a significant improvement of the homogeneity of the final structure of the composite. ${ }^{34}$

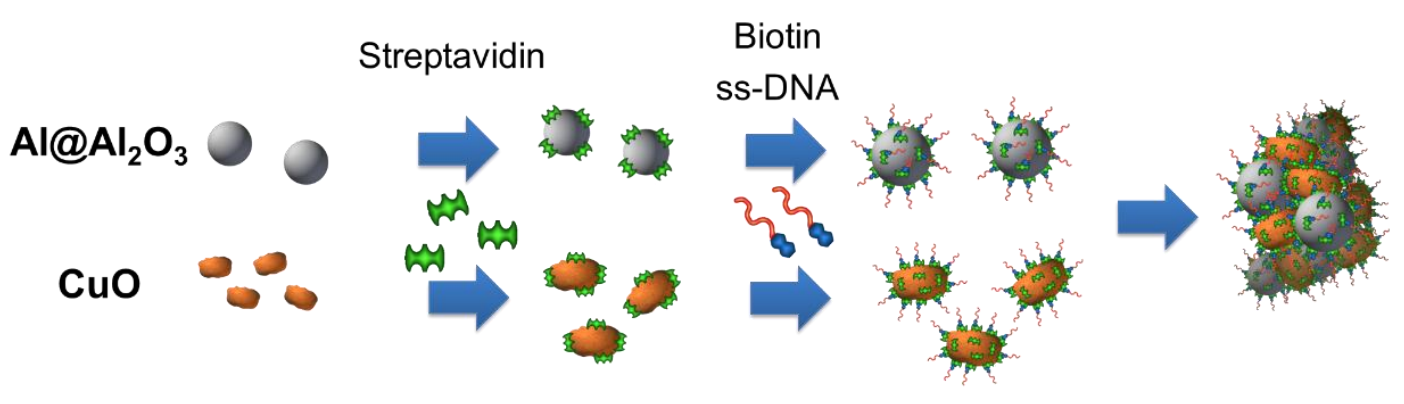

Figure 1. Illustration of the functionalization process developed to enable the DNA-directed self-assembly of $\mathrm{Al} @ \mathrm{Al}_{2} \mathrm{O}_{3}$ and $\mathrm{CuO}$ nanoparticles. 
We further investigate the bio-functionalization of $\mathrm{Al} @ \mathrm{Al}_{2} \mathrm{O}_{3}$ and $\mathrm{CuO}$ nanoparticles by performing, for the first time, a complete characterization of streptavidin and DNA grafting densities and hybridization efficiency on nanoparticles. The objectives of this work are to: (i) quantify streptavidin and DNA oligonucleotides coverages, (ii) optimize basic experimental parameters such as salt concentration, incubation time and degree of sonication (usually studied for gold nanoparticles) to maximize DNA loading, and (iii) determine the specificity of grafted DNAs, and quantify their concentrations and their resulting ability to hybridize to a complementary strand. This study relies on characterization of the functionalization process not only with techniques that are standard in the field of DNA-based self-assembly, such as dynamic light scattering (DLS) $)^{28,35,36}$ and fluorimetry, ${ }^{25,32,33,36-38}$ but also with more unconventional methods like atomic absorption spectroscopy (AAS) for the determination of $\mathrm{Al} @ \mathrm{Al}_{2} \mathrm{O}_{3}$ and $\mathrm{CuO}$ nanoparticles concentrations. ${ }^{39-41}$ To avoid fluorescence quenching by nanoparticles (as observed for many metal oxides such ITOs) ${ }^{42}$, the quantification was obtained by comparing fluorescence intensity of supernatant solutions only.

Importantly, our results show that non-specific interactions dominate between DNA and $\mathrm{Al} @ \mathrm{Al}_{2} \mathrm{O}_{3}$ and $\mathrm{CuO}$ nanoparticles during functionalization, leading to a poor hybridization specificity of 5 to $10 \%$ of all grafted DNA. However, the use of streptavidin results in a significant improvement of the specificity compared to DNA oligonucleotides directly grafted on nanoparticles. The molecular investigation on the structure of grafted DNA suggests a conformation that is clearly different from the standing up arrangement obtained with gold nanoparticles. More precisely, DNA oligonucleotides seem to lay down at the surface in a complex mixed distribution. We believe that these findings and the associated methodology to quantify hybridization efficiency will support the development of novel grafting strategies to 
better adapt the grafting process to the desired application. Altogether, they represent a significant step for developing DNA nanotechnologies dealing with metal oxide materials.

\section{EXPERIMENTAL SECTION}

\section{Reagents.}

$\mathrm{NaCl}$ powder, monobasic and dibasic sodium $\mathrm{NaH}_{2} \mathrm{PO}_{4}$ and $\mathrm{NaHPO}_{4}{ }^{-}$powders, phosphatebuffered saline 10X (denoted PBS), and surfactant Tween 20 were purchased from SigmaAldrich. Phosphate buffer (denoted PB, $0.2 \mathrm{M}$ ) at $\mathrm{pH} 7$ was obtained by mixing monobasic and dibasic powders ( $39 \%$ vol. and $61 \%$ vol., respectively). $\mathrm{NaCl}$ solutions ( $2 \mathrm{M}$ ) were prepared by dissolution of $\mathrm{NaCl}$ powder in ultra-pure water.

Streptavidin protein with and without fluorescent dye Cy3 was purchased from Sigma-Aldrich. Sequences of biotinylated-oligonucleotides were designed as detailed in ${ }^{29}$ and are reported in Table 1. FAM-labelled biotinylated-oligonucleotides were purchased from Eurogentec in a dried form and then diluted as received in ultra-pure water concentrated at $0.5 \mathrm{mM}$. The spacer is made of $x$ repeated thymines (denoted $-(\mathrm{T})_{x}$ in Table 1).

Table 1. Sequences of oligonucleotides functionalized with biotin and fluorescein amidite (FAM) used in this work.

\begin{tabular}{cl}
\hline Name & Sequence (5' to 3') \\
\hline \hline ss-A $_{\mathrm{x}}$ & Biotin-(T) $)_{\mathrm{x}}$-ACA-TCG-CCC-CGC-CT-6FAM \\
ss-B & Biotin-(T) $)_{\mathrm{x}}$-AGG-CGG-GGC-GAT-GT-6FAM \\
\hline
\end{tabular}


$\mathrm{CuO}$ nanopowders (50 nm, facetted nanoparticles) were purchased from Sigma-Aldrich. $\mathrm{Al} @ \mathrm{Al}_{2} \mathrm{O}_{3}$ nanopowders $(70 \mathrm{~nm}$, spherical Al nanoparticles coated with an alumina shell) were purchased from US Research Nanomaterials (Austin, TX). Morphological and size distribution characterizations are reported in SI, Figure S1.

\section{Preparation of colloidal suspensions and self-assembly process.}

$\mathrm{Al} @ \mathrm{Al}_{2} \mathrm{O}_{3}(14.5 \mathrm{mg})$ and $\mathrm{CuO}(13 \mathrm{mg})$ nanopowders were separately suspended in an aqueous solution composed of $10 \mathrm{mM}$ PB $(\mathrm{pH}=7.3 \text {, limiting nanoparticle oxidation })^{45}$ and 0.05 vol. $\%$ Tween 20 in ultra-pure de-ionized water. Tween 20 was chosen as a surfactant to increase nanoparticles stability and because it does not interfere with biological interactions (an important point when considering the biotin-streptavidin complexation). ${ }^{28}$ The nanoparticles were then placed on a shaker and sonicated for 8 min. The mass of the $\mathrm{Al} @ \mathrm{Al}_{2} \mathrm{O}_{3}$ and $\mathrm{CuO}$ powders and the sonication time were optimized using a Doehlert Design of Experiment. The nanoparticle concentration was then determined from the hydrodynamic diameter of nanoparticles measured by DLS and $\mathrm{Cu}$ and $\mathrm{Al} @ \mathrm{Al}_{2} \mathrm{O}_{3}$ mass concentrations measured by AAS (see SI, Figure S2 for calculation method). For the calculation of nanoparticle concentrations, note that colloidal suspensions are assimilated to monodisperse spherical particles with a diameter corresponding to the mean hydrodynamic diameter measured by DLS. The final solution composition (buffer, salt and surfactant concentration) was optimized to maximize nanoparticle concentration and minimize their hydrodynamic diameter (see SI, Figure S3). All sets of experiments showed very good repeatability of the dispersion protocol and colloid preparation, despite the high number of parameters involved in the process (see SI, Figure S4). 
After a sedimentation time of $24 \mathrm{~h}, 20 \mathrm{~mL}$ of optimized supernatant of each colloidal suspension was re-suspended in a centrifuge tube. After the addition of $30 \mu \mathrm{L}$ of streptavidin $(1 \mathrm{mg} / \mathrm{mL})$, the solutions were homogenized by vortexing for $10 \mathrm{~s}$ and then sonicated for $5 \mathrm{~min}$. After an incubation period of $8 \mathrm{~h}$, the solution was rinsed with aqueous buffer (PBS 0.1X, 0.05 vo.\% Tween 20 and pure water) to remove excess protein and to slightly increase the ionic concentration (so as to screen negative repulsive charges of DNA strands added in the next step). Rinsing involved three consecutive steps of centrifugation at 10,000 $\mathrm{G}$ for $10 \mathrm{~min}$ and dispersion by sonication for $5 \mathrm{~min}$. Note that after the rinsing step, only $10 \%$ of the nanoparticles are lost in both the $\mathrm{Al} @ \mathrm{Al}_{2} \mathrm{O}_{3}$ and $\mathrm{CuO}$ colloidal suspensions.

$10 \mu \mathrm{L}$ of biotinylated DNA at a concentration of $0.5 \mathrm{mM}$ was subsequently added to the $20 \mathrm{~mL}$ colloidal suspensions. After an incubation time of $8 \mathrm{~h}$, the solution was rinsed with an aqueous buffer (PBS 0.1X, 0.05 vol.\% Tween 20 and pure water) to remove excess DNA.

Hydrodynamic diameters and zeta potentials of each $\mathrm{Al} @ \mathrm{Al}_{2} \mathrm{O}_{3}$ and $\mathrm{CuO}$ suspension before and after biological species functionalization are reported in SI, Table S5. Any clear morphological modification was detected by SEM imaging after functionalization of nanoparticles (see SI,

Figure S6).

A control experiment was prepared with colloidal suspensions of $\mathrm{CuO}$ and $\mathrm{Al} @ \mathrm{Al}_{2} \mathrm{O}_{3}$ nanoparticles coated with DNA strands without streptavidin coating. The previously described parameters were used: $1 \mu \mathrm{L}$ of DNA at a concentration of $0.5 \mathrm{mM}$ was added to $1 \mathrm{~mL}$ of $\mathrm{CuO}$ and $\mathrm{Al} @ \mathrm{Al}_{2} \mathrm{O}_{3}$ colloidal suspensions. After an incubation time of $24 \mathrm{~h}$, the solution was rinsed in an aqueous buffer (PBS 0.1X, 0.05\% vol:vol Tween 20 and pure water). Note that identical 
sequences of the DNA strands (reported in Table 1, i.e. with the biotin function) were used for the control experiment.

After functionalization, DNA-modified $\mathrm{Al} @ \mathrm{Al}_{2} \mathrm{O}_{3}$ and $\mathrm{CuO}$ nanoparticles were mixed in "stoichiometric" proportion, i.e. equimolar of number of nanoparticles. Typically, 500 of mixed colloidal solutions were prepared with a volume ratio of 2.10 for $\mathrm{CuO}: \mathrm{Al}$. $\mathrm{NaCl}$ salt was added to the solution in order to reach a final concentration of $35 \mathrm{mM}$. According to our previous work, ${ }^{34}$ this concentration limits unspecific interactions, i.e. interactions between nanoparticles despite of presence of DNA. In order to confirm the functionalization of nanoparticles and efficiency of DNA hybridization, a control experiment was realized with colloidal suspensions of $\mathrm{Al} @ \mathrm{Al}_{2} \mathrm{O}_{3}$ and $\mathrm{CuO}$ nanoparticles without complementary strands (ss- $\mathrm{A}_{15}$ was grafted on both nanoparticles). Aggregation kinetics obtained by DLS measurements were compared and SEM imaging of nanocomposites obtained after self-assembling nanoparticles by depositing one drop on a nickel TEM grid. Results are reported in SI, Figure S7.

\section{Nanoparticle characterization.}

Atomic absorption spectroscopy (AAS) was performed on an AAnalyst 200 from PerkinElmer Instruments equipped with an acetylene flame for $\mathrm{CuO}$ colloids and a mix of acetylene and nitrous oxide for $\mathrm{Al} @ \mathrm{Al}_{2} \mathrm{O}_{3}$ colloids to determine the concentrations of nanoparticles in the colloidal suspensions. A Zetasizer Nano ZS instrument (Malvern Instruments) was used to determine the nanoparticle hydrodynamic diameters by DLS, and zeta potentials were determined by Doppler laser electrophoresis. The signal of a He/Ne laser emitting at $632.8 \mathrm{~nm}$ interacts with a measurement cell of $150 \mu \mathrm{L}$ or $850 \mu \mathrm{L}$ for hydrodynamic or zeta potential analyses, respectively. All zeta potential and hydrodynamic diameter measurements were 
performed at $25{ }^{\circ} \mathrm{C}$ and at a $\mathrm{pH}$ of 7.3. Fluorescence measurements were performed in a Varioskan Flash instrument using 96-well flat-bottom plates able to contain $400 \mu \mathrm{L}$ of solution. All procedures involving fluorescence were conducted in the dark to prevent photobleaching of the fluorescein and Cy3 dyes. The excitation wavelengths were fixed at $550 \mathrm{~nm}$ and $495 \mathrm{~nm}$ for Cy3-labelled streptavidin and FAM-labelled oligonucleotides, respectively, and the corresponding emission spectra were recorded for wavelengths greater than 570 and $518 \mathrm{~nm}$. The fluorescence intensity of control samples was measured to determine the streptavidin and oligonucleotide concentrations in solution by radiometry.

\section{Quantification of DNA and streptavidin surface densities.}

The overall quantification procedure is detailed in Figure 2, covering three steps of interest to determine streptavidin surface density, DNA surface density and hybridization efficiency. Fluorescence analyses are based on indirect measurements: only supernatant fluorescence was measured in order to avoid quenching induced by the presence of nanoparticles. However, quantification requires prior knowledge of the $\mathrm{Al} @ \mathrm{Al}_{2} \mathrm{O}_{3}$ and $\mathrm{CuO}$ nanoparticle concentrations; $1 \mu \mathrm{L}$ of $\mathrm{HCl}$ was added to $1 \mathrm{~mL}$ of $\mathrm{CuO}$ colloidal suspension to dissolve the particles, and $6.5 \mu \mathrm{L}$ of $\mathrm{HNO}_{3}$ was added to $10 \mathrm{~mL}$ of $\mathrm{Al} @ \mathrm{Al}_{2} \mathrm{O}_{3}$ colloidal suspensions to dissolve the particles. The concentrations of $\mathrm{Cu}$ and $\mathrm{Al} @ \mathrm{Al}_{2} \mathrm{O}_{3}$ nanoparticles were then determined by AAS. 


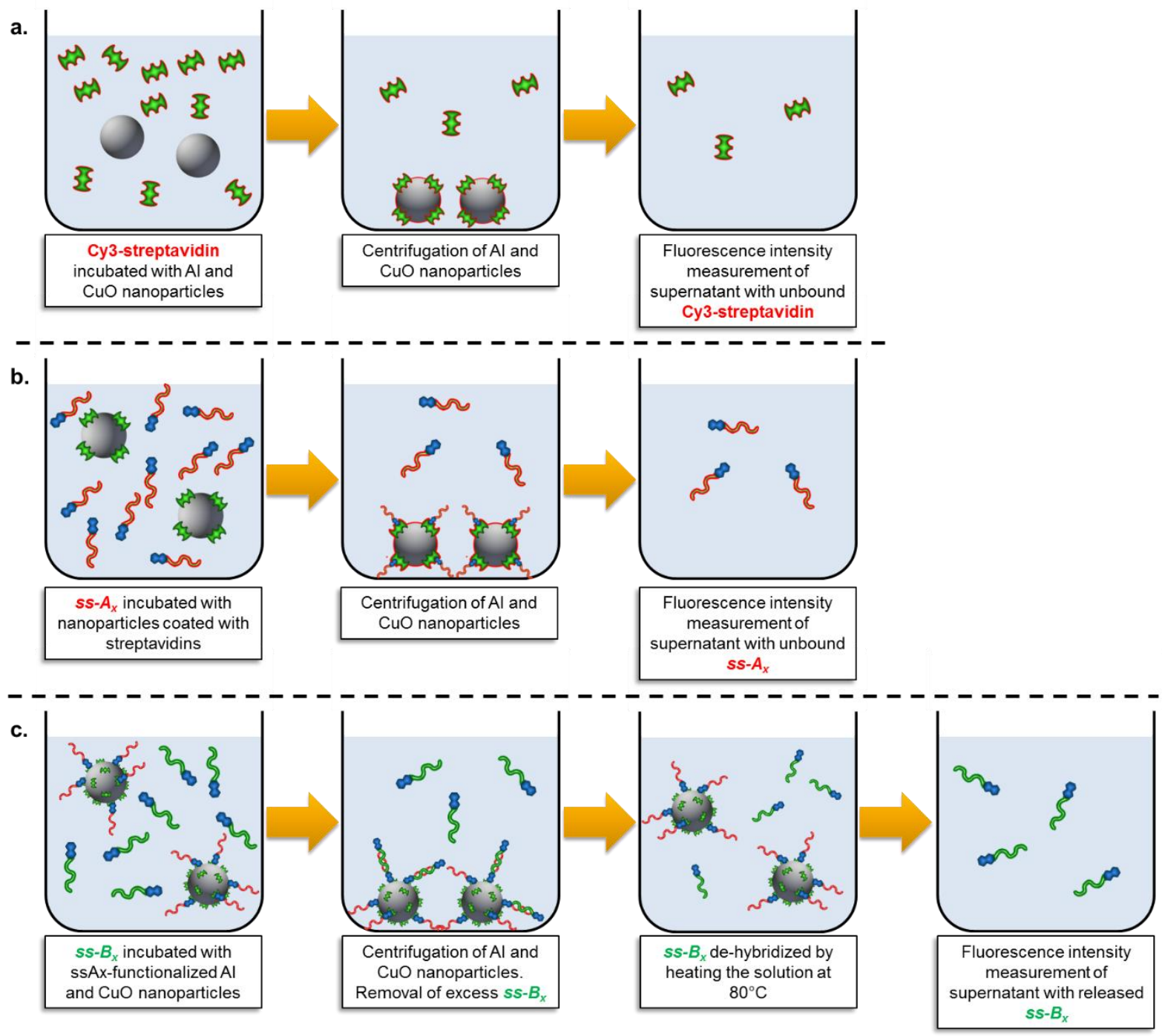

Figure 2. Schematic representation of the process developed for the determination of (a) streptavidin surface density on $\mathrm{CuO}$ or $\mathrm{Al} @ \mathrm{Al}_{2} \mathrm{O}_{3}$ nanoparticles, (b) the DNA surface density on $\mathrm{CuO}$ or $\mathrm{Al} @ \mathrm{Al}_{2} \mathrm{O}_{3}$ nanoparticles and (c) the hybridization efficiency on $\mathrm{CuO}$ or $\mathrm{Al} @ \mathrm{Al}_{2} \mathrm{O}_{3}$ nanoparticles.

\section{Quantification of streptavidin surface density.}

$1 \mu \mathrm{L}$ of $\mathrm{Cy} 3$-labeled streptavidin was added to $500 \mu \mathrm{L}$ of colloidal suspensions. After an incubation of $8 \mathrm{~h}$, the solutions were centrifuged, and the fraction of unbound streptavidin 
(Figure 2a) was measured in the supernatant. The difference in streptavidin concentration before and after centrifugation was used to deduce the amount of bound streptavidin, which was then normalized by the quantity of nanoparticles determined by AAS.

Quantification of DNA surface density.

$1 \mu \mathrm{L}$ of FAM-oligonucleotides $\left(s s-A_{x}\right)$ was added to $500 \mu \mathrm{L}$ of colloidal suspensions of streptavidin-modified nanoparticles. After an incubation of $8 \mathrm{~h}$, the solutions were centrifuged, and the fluorescence intensity of the supernatant was measured. The quantity of DNA grafted on the nanoparticles was then obtained from the difference between the initial DNA concentration (using a control sample) and the DNA concentration in the supernatant, which was finally normalized by the quantity of nanoparticles determined by AAS. This protocol is summarized in Figure $2 \mathbf{b}$. Note that the reversibility of the streptavidin/biotin bonding was evaluated by heating the solutions containing functionalized $\mathrm{Al} @ \mathrm{Al}_{2} \mathrm{O}_{3}$ and $\mathrm{CuO}$ nanoparticles in a SDS $0.1 \%$ solvent for $10 \mathrm{~min}$. The fluorescence intensity was measured in the supernatant after centrifugation of colloids but no signal was detected. In contrast, the same experiment conducted with streptavidin-functionalized micrometric polymeric beads showed the reversibility of the biotinstreptavidin bond under the same conditions. This observation suggests that the released DNA could be adsorbed on the nanoparticle surface as soon as the biotin-streptavidin bond breaks.

\section{DNA hybridization efficiency characterization.}

$1 \mu \mathrm{L}$ of FAM-labelled oligonucleotides $\left(s s-B_{x}\right)$ was added to $500 \mu \mathrm{L}$ of $\mathrm{Al} @ \mathrm{Al}_{2} \mathrm{O}_{3}$ and $\mathrm{CuO}$ colloidal suspensions previously functionalized with non-fluorescent $s s-A_{x}$ strands. The $\mathrm{NaCl}$ concentration was then set to $35 \mathrm{mM}$ to enable the hybridization of the FAM-labelled $s s-B_{x}$ with the $s s-A_{x}$ grafted on the $\mathrm{Al} @ \mathrm{Al}_{2} \mathrm{O}_{3}$ and $\mathrm{CuO}$ nanoparticles. After a few hours, the colloids were 
centrifuged and re-suspended in $500 \mu \mathrm{L}$ of PBS $0.1 \mathrm{X}$, Tween 0.05 vol. $\%$ and $35 \mathrm{mM} \mathrm{NaCl}$ to remove excess DNA strands. After rinsing, the solutions were finally heated to $80{ }^{\circ} \mathrm{C}$ for $5 \mathrm{~min}$ to de-hybridize the $s s-B_{x}$ strands. The fluorescence intensity of the supernatant containing the released $s s-B_{x}$ strands was measured, and the quantity of DNA strands grafted on the nanoparticles was calculated (see Figure 2c).

\section{Statistical Analysis.}

The loading of streptavidin and DNA strands on both $\mathrm{Al} @ \mathrm{Al}_{2} \mathrm{O}_{3}$ and $\mathrm{CuO}$ nanoparticles were conducted three times independently for each data point presented in the Results section. Standard deviations were obtained by propagation of uncertainty. Uncertainties of each parameter measured to calculate the grafting density were obtained by repeating the measurement three times for each individual sample. The nanoparticle concentrations with their standard deviations were obtained by calculating the average of five independent colloidal suspensions. The effect of rinsing on colloid concentrations was taken into account: a loss of $10 \%$ of the nanoparticle concentration is included after both streptavidin and DNA rinsing steps. Regular measurements of random isolated samples were conducted to check the consistency of calculated nanoparticle concentrations.

\section{RESULTS AND DISCUSSION}

\section{Streptavidin and DNA loadings quantification}

As for most biological processes, quantification of assembly methods requires a systematic approach. For this purpose, we first present the dependence of streptavidin and DNA grafting densities on basic process parameters (such as incubation time, salt concentration, and sonication 
parameters) with an initial aim to find an optimized set of parameters to maximize the loading of DNA or proteins on these nano-objects.

The preliminary characterization consists in measuring the physical parameters of $\mathrm{Al} @ \mathrm{Al}_{2} \mathrm{O}_{3}$ and $\mathrm{CuO}$ colloidal suspensions before any type of surface modification by DLS and AAS analyses. First, it is important to note the morphological differences between commercialized $\mathrm{CuO}$ and $\mathrm{Al} @ \mathrm{Al}_{2} \mathrm{O}_{3}$ nanoparticles, as illustrated in SI, Figure S1. CuO nanoparticles are small, nonspherical and highly facetted, whereas $\mathrm{Al} @ \mathrm{Al}_{2} \mathrm{O}_{3}$ nanoparticles are perfectly spherical with a smooth surface. For $\mathrm{CuO}$ colloids, the average hydrodynamic diameter of nanoparticles is $185 \pm$ $5 \mathrm{~nm}$, and the nanoparticle concentration is $(5.7 \pm 0.7) \times 10^{9}$ nanoparticles. $\mathrm{mL}^{-1}$, calculated using the value of $\mathrm{Cu}$ concentration obtained by AAS (100 $\pm 10 \mathrm{mg} \cdot \mathrm{L}^{-1}$, see Methods section). For $\mathrm{Al} @ \mathrm{Al}_{2} \mathrm{O}_{3}$ colloids, the average diameter is $195 \pm 5 \mathrm{~nm}$, and the nanoparticle concentration is $(1.2 \pm 0.1) \times 10^{10}$ nanoparticles.mL $\mathrm{m}^{-1}$ given the $\mathrm{Al} @ \mathrm{Al}_{2} \mathrm{O}_{3}$ concentration of $125 \pm 10 \mathrm{mg} \cdot \mathrm{mL}^{-1}$. $\mathrm{Al} @ \mathrm{Al}_{2} \mathrm{O}_{3}$ and $\mathrm{CuO}$ suspensions both exhibit high absolute zeta potentials of $-50.2 \pm 1.0 \mathrm{mV}$ and $-46.3 \pm 1.8 \mathrm{mV}$, respectively, indicating a very good stability of the colloids (see Methods section). This negative charge could be mainly caused by large adsorption of phosphate on oxide surfaces, as observed for $\mathrm{Fe}_{3} \mathrm{O}_{4}, \mathrm{CeO}_{2}$ or $\mathrm{TiO}_{2}{ }^{10,32,33}$

\section{Attachment of streptavidin on nanoparticles.}

The streptavidin surface density is first measured as a function of incubation time from 1 to $30 \mathrm{~h}$ and reported in Figure 3a for both $\mathrm{Al} @ \mathrm{Al}_{2} \mathrm{O}_{3}$ and $\mathrm{CuO}$ colloids, following the procedure summarized in Methods section. The amount of streptavidin per nanoparticle appears to be

relatively stable with approximately $(6.4 \pm 0.9) \times 10^{11}$ and $(4.4 \pm 0.7) \times 10^{11}$ proteins. $\mathrm{cm}^{-2}$ for the $\mathrm{CuO}$ and $\mathrm{Al} @ \mathrm{Al}_{2} \mathrm{O}_{3}$ nanoparticles, respectively. Since the size of streptavidin is $4 \times 4.2 \times 5$ 
$\mathrm{nm}^{3},{ }^{43}$ the surface coverage ratio is inferred to be $\sim 11 \%$ and $\sim 6 \%$ for $\mathrm{CuO}$ and $\mathrm{Al} @, \mathrm{Al}_{2} \mathrm{O}_{3}$

respectively. These results are consistent with Castelino's study ${ }^{25}$ that reported a surface loading of $4.6 \times 10^{11}$ antigen molecules per $\mathrm{cm}^{2}$ on streptavidin-functionalized gold surfaces, using a biotin-modified antigen detection. However, the reason for the difference of streptavidin loading between $\mathrm{Al} @ \mathrm{Al}_{2} \mathrm{O}_{3}$ and $\mathrm{CuO}$ nanoparticles must be taken with caution. The roughness and faceting of $\mathrm{CuO}$ nanoparticles as well as their aggregation propensity (see SI, Figure S1), lead to an underestimation of the total surface available as we approximate nanoparticles as hard spheres (implied by DLS measurement). Nevertheless, these results confirmed the fast action of nonspecific interaction of streptavidin on solid surfaces, which takes place within an hour. For all experiments thereafter, the incubation time is set to $8 \mathrm{~h}$ to improve the repeatability from one batch to another.
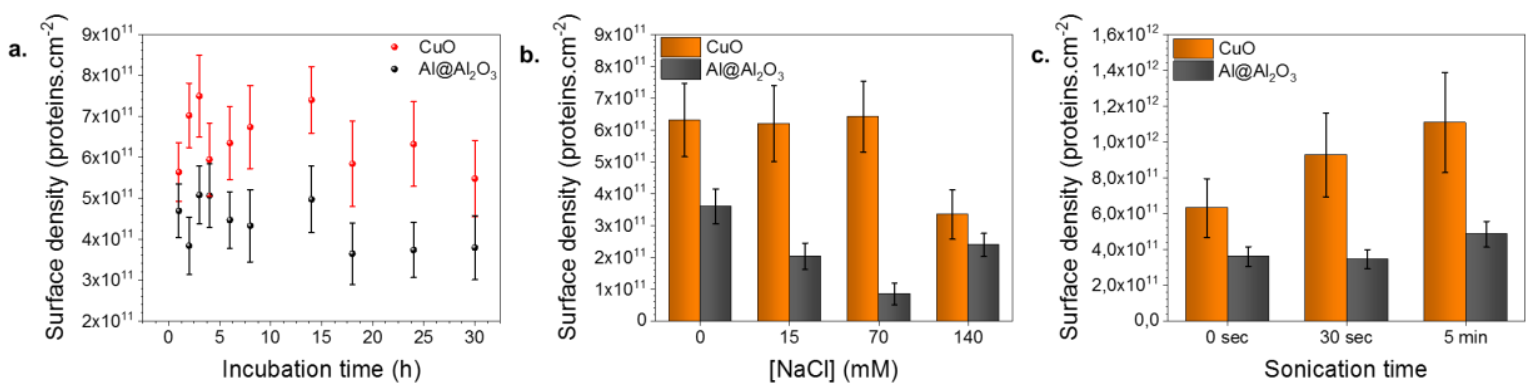

Figure 3. Streptavidin surface density on $\mathrm{CuO}$ (red circles, orange bars) and $\mathrm{Al}$ (black circles, grey bars) nanoparticles as a function of (a) incubation time in PB at $10 \mathrm{mM}$ and Tween 20 surfactant at $0.05 \%$ vol:vol; (b) salt concentration with $8 \mathrm{~h}$ incubation time; (c) sonication time prior to the incubation set to $8 \mathrm{~h}$ in same solvent as (a). Each data point is obtained by repeating each experiment three times. Error bars are calculated by propagation of uncertainty, determined for each parameter in the calculation of streptavidin surface density. Note that this procedure is applied to every dataset plotted in this report. 
The streptavidin surface density as a function of $\mathrm{NaCl}$ concentration is presented in Figure $\mathbf{3 b}$ for $\mathrm{Al} @ \mathrm{Al}_{2} \mathrm{O}_{3}$ and $\mathrm{CuO}$ colloids. Salt is added to the colloidal suspensions at concentrations ranging from 0 to $140 \mathrm{mM}$ while maintaining the same nanoparticle and streptavidin concentration. We observe that $\mathrm{Al} @ \mathrm{Al}_{2} \mathrm{O}_{3}$ and $\mathrm{CuO}$ colloidal suspensions behave differently. In the case of $\mathrm{CuO}$, the streptavidin surface density remains stable and constant at $\sim 6.3 \times 10^{11}$ proteins. $\mathrm{cm}^{-2}(\sim 710$ proteins per nanoparticle) for $\mathrm{NaCl}$ concentrations in the range of 0-70 $\mathrm{mM}$, corresponding to a streptavidin coverage ratio of $10.6 \pm 1.9 \%$. Above $70 \mathrm{mM}$, the protein density decreases by a factor of 2 . This increase in salt concentration also leads to a decrease in zeta potential from $-46.3 \pm 1.8$ to $-20.5 \pm 0.9 \mathrm{mV}$, indicating that the inter-particle repulsion is reduced, thus favoring irreversible aggregations between nanoparticles. Consequently, the available specific surface is lower, and the streptavidin density is reduced.

For $\mathrm{Al} @ \mathrm{Al}_{2} \mathrm{O}_{3}$ colloids, the effect of salt concentration is even more pronounced: the maximum surface density is $\sim 3.6 \times 10^{11}$ proteins.cm ${ }^{-2}(\sim 620$ proteins per nanoparticle) without salt, and it decreases to $\sim 2.0 \times 10^{11}$ proteins. $\mathrm{cm}^{-2}$ and to $0.9 \times 10^{11}$ proteins. $\mathrm{cm}^{-2}$ for concentrations of 15 and $70 \mathrm{mM} \mathrm{NaCl}$, respectively. Without salt, the streptavidin coverage ratio is estimated to be $6.0 \pm 0.9 \%$. The slight increase of the coverage observed at $140 \mathrm{mM}$ could be explained by a more pronounced adsorption of streptavidin on the $\mathrm{Al}_{2} \mathrm{O}_{3}$ surface because of the reduction of repulsive charges between nanoparticles and streptavidin (which compensates for the lower available surface of aggregated nanoparticles). At this stage, we can conclude that streptavidin loading is optimal without salt for both colloids. As reported in the SI, Figure S6, no clear surface modification of the surface is detected by SEM analysis for both colloids.

The effect of sonication at the first stages of streptavidin incubation is presented in Figure 3c. After $5 \mathrm{~min}$ of sonication, the streptavidin surface density increases nearly two-fold from 6.3 to 
$11.1 \times 10^{11}$ proteins. $\mathrm{cm}^{-2}\left(\sim 710\right.$ to 1250 proteins per nanoparticle) and from 4.3 to $5.3 \times 10^{11}$ proteins.cm ${ }^{-2}$ (620 to 830 proteins per nanoparticle) for $\mathrm{CuO}$ and $\mathrm{Al} @ \mathrm{Al}_{2} \mathrm{O}_{3}$ colloids, respectively. Such a sonication-induced increase in streptavidin coverage is in agreement with previous works on DNA loading, ${ }^{37}$ and prevents nanoparticle aggregation that typically hinders further reaction at the surface. Therefore, the streptavidin coating is found to be maximized after 5 min of sonication in PB at $10 \mathrm{mM}$ and Tween 20 at $0.05 \mathrm{vol} \%$, and the streptavidin surface coverage ratio plateaus at $19 \pm 4 \%$ and $9 \pm 2 \%$ for the $\mathrm{CuO}$ and $\mathrm{Al} @ \mathrm{Al}_{2} \mathrm{O}_{3}$ nanoparticles, respectively. Considering the sticky property of streptavidin, ${ }^{44}$ these surface coverages appear to be much less important than expected. At this stage, it could be due to repulsive interactions between nanoparticles and proteins, both negatively charged in PB solvent.

Overall, the optimal set of basic parameters (salt and surfactant concentrations, sonication) is composed of an incubation time of $8 \mathrm{~h}$, an aqueous solvent composed of $10 \mathrm{mM}$ PB and 0.05 vol.\% of surfactant Tween 20 , and 5 min of sonication prior to the incubation.

\section{Attachment of biotinylated single-stranded DNA on streptavidin-coated nanoparticles.}

Starting from $\mathrm{Al} @ \mathrm{Al}_{2} \mathrm{O}_{3}$ and $\mathrm{CuO}$ suspensions functionalized with streptavidin under optimal conditions, Figure 4 shows the surface densities of DNA strands grafted through their biotin moiety as a function of incubation time, $\mathrm{NaCl}$ concentration, and oligonucleotide length. Note that nanoparticles functionalized with streptavidin are dispersed in PBS 0.1X (PB $10 \mathrm{mM}$ and $\mathrm{NaCl}$ concentration of $15 \mathrm{mM}$ ) and Tween 20 at 0.05 vol.\% in order to favor the complexation of biotin-modified DNA strands on streptavidin (see the Methods section). Three types of singlestranded oligonucleotides are considered, $s s-A_{x}$ is composed of a spacer containing $x$ repeated thymines, with $x=0,15$ and 30 (See Table 1). Since 5 min sonication at the beginning of the 
incubation increases the DNA surface density, this step is always incorporated in our functionalization protocol. Note that identical sequences are used with and without streptavidin.

Figure 4a shows the biotinylated single-stranded DNA $\left(s s-A_{x}\right)$ surface density as a function of incubation time from 1 to $30 \mathrm{~h}$. The grafting densities appear to be independent of the incubation time at $(4.0 \pm 0.6) \times 10^{13}$ and $(8.5 \pm 2.8) \times 10^{12}$ strands.cm ${ }^{-2}$ for $\mathrm{CuO}$ and $\mathrm{Al} @ \mathrm{Al}_{2} \mathrm{O}_{3}$

nanoparticles, respectively. These surface densities are similar to values published in the literature for a range of substrates. For example, Hurst et al. report a DNA surface concentration of 9 to $12 \times 10^{12}$ strands.cm ${ }^{-2}\left(15\right.$ to 20 pmol.cm ${ }^{-2}$ ) on gold nanoparticles with diameters ranging from 150 to $250 \mathrm{~nm} \cdot{ }^{37}$ Notably, the grafting density on $\mathrm{CuO}$ nanoparticles is 4 to 5 times greater than on $\mathrm{Al} @ \mathrm{Al}_{2} \mathrm{O}_{3}$ nanoparticles, despite their smaller hydrodynamic diameter. This can be partly explained by the higher streptavidin coverage on the $\mathrm{CuO}$ surface and the approximation of $\mathrm{CuO}$ nanoparticles as perfect spheres, as mentioned before. As for the streptavidin coating, this set of experiments shows that the biotinylated DNA grafting process is rapid and takes place in less than $1 \mathrm{~h}$. Since there is no time dependence, an incubation time of $8 \mathrm{~h}$ was selected to maintain a constant set of parameters for all experiments.
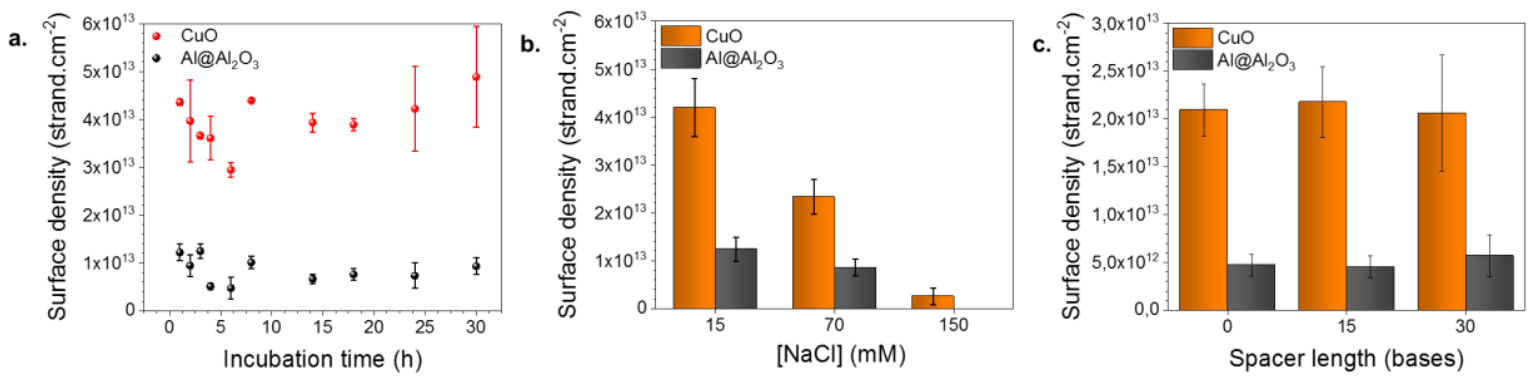

Figure 4. $s s-A_{30}$ surface density on $\mathrm{CuO}$ (red circles, orange bars) and $\mathrm{Al}$ nanoparticles (black circles, grey bars) as a function of (a) incubation time in PBS 0.1X and Tween 20 at 0.05 vol.\% (b) salt concentration, after $8 \mathrm{~h}$ of incubation time; (c) the length of the spacer after $8 \mathrm{~h}$ of 
incubation in same solvent than (a). Sonication of $5 \mathrm{~min}$ is performed at the beginning of the incubation for all experiments.

As shown in Figure $\mathbf{4 b}$, the $s s-A_{30}$ strand surface density strongly depends on the $\mathrm{NaCl}$ concentration. For $\mathrm{CuO}$ colloids, the DNA surface densities are $(4.2 \pm 0.6) \times 10^{13},(2.3 \pm 0.4) \times$ $10^{13}$, and $(2.6 \pm 1.7) \times 10^{12}$ strands.cm ${ }^{-2}$ for $\mathrm{NaCl}$ concentrations of 15,70 and $150 \mathrm{mM}$, respectively. For $\mathrm{Al} @ \mathrm{Al}_{2} \mathrm{O}_{3}$ colloids, the DNA surface density decreases from $(1.2 \pm 0.3) \times 10^{13}$ to $(8.6 \pm 1.8) \times 10^{12}$ strands. $\mathrm{cm}^{-2}$ for $\mathrm{NaCl}$ concentrations of 15 and $70 \mathrm{mM}$, respectively. Note that we could not detect DNA on $\mathrm{Al} @ \mathrm{Al}_{2} \mathrm{O}_{3}$ nanoparticle surfaces for $150 \mathrm{mM} \mathrm{NaCl}$. Interestingly, this trend is opposite to that reported in the literature for gold colloids. In general, higher salt concentrations make it possible to reach higher DNA grafting because of the reduction of repulsive negative forces between DNA strands. For instance, an optimized $\mathrm{NaCl}$ concentration of $700 \mathrm{mM}$ has been reported for Gold NPs. ${ }^{37}$ In contrast, for our nanoparticles, we find that the optimized $\mathrm{NaCl}$ concentration is $15 \mathrm{mM}$. Similar experiments conducted without surfactant confirmed this conclusion, but all DNA grafting densities were smaller regardless of the $\mathrm{NaCl}$ concentration, justifying the use of surfactant (results not shown).

The $\mathrm{NaCl}$ concentration is a key parameter to stabilize $\mathrm{Al} @ \mathrm{Al}_{2} \mathrm{O}_{3}$ and $\mathrm{CuO}$ colloidal suspensions, and the reduction of the repulsive forces between DNA strands contributes marginally to the grafting of DNA on the nanoparticles. Increasing the $\mathrm{NaCl}$ concentration leads to the rapid aggregation of nanoparticles and hence limits the surface available for DNA grafting. In fact, salt-induced aging procedures of colloids lead to an irreversible aggregation of nanoparticles in our system, because of their high sensitivity to the $\mathrm{NaCl}$ concentration despite a small increase of the ionic concentration (from 15 to $70 \mathrm{mM}$ in increments of $10 \mathrm{mM}$, not shown). Figure $\mathbf{4 b}$ also shows that, regardless of $\mathrm{NaCl}$ concentration, the number of DNA 
strands grafted on $\mathrm{CuO}$ nanoparticles is greater than that on $\mathrm{Al}$ particles. This can be partially explained by the underestimation of the available surface area of $\mathrm{CuO}$ nanoparticles, approximated as perfect spheres.

We now investigate the impact of the single-stranded oligonucleotide length on the DNA grafting density. For this purpose, the DNA grafting step is performed in PBS $0.1 \mathrm{X}$ and Tween $20(0.05$ vol.\%) preceded by $5 \mathrm{~min}$ of sonication and with an incubation time of $8 \mathrm{~h}$. No additional $\mathrm{NaCl}$ is added. Figure $4 \mathbf{c}$ shows that the DNA surface density is independent of the spacer length. For $\mathrm{CuO}$ nanoparticles, we estimate that $\sim 23,000$ strands are attached to nanoparticles ( 2.1 to $2.2 \times 10^{13}$ strand. $\mathrm{cm}^{-2}$ ), i.e. more than 20 times the amount of streptavidin available on the surface ( 1,250 proteins per nanoparticle, see Figure 4a). Our results are not consistent with observations for gold colloids, where an increase in spacer lengths leads to a decrease in DNA grafting densities. ${ }^{25,37}$ Therefore, the loading of $\mathrm{CuO}$ nanoparticles is nearly three times higher than the loading measured for gold colloids $(8,500$ oligonucleotides composed of 25 bases on $200 \mathrm{~nm}$ gold nanoparticles). ${ }^{36}$ Given the fraction of free $\mathrm{CuO}$ surface after streptavidin coating (considered as available surface for direct DNA grafting), we deduce that $95 \%$ of the $s s-A_{x}$ strands are directly chemisorbed on $\mathrm{CuO}$ and that the remaining $\sim 5 \%$ is grafted via the biotin moiety on the streptavidin sites. Note that theoretically, each streptavidin can host up to four biotin groups in solution; this number decreases to around two after streptavidin grafting.

Similarly, for $\mathrm{Al} @ \mathrm{Al}_{2} \mathrm{O}_{3}$ nanoparticles, the DNA surface density ranges from 6,000 to 7,500 strands per nanoparticle ( 4.5 to $5.7 \times 10^{12}$ strands. $\mathrm{cm}^{-2}$ ) with a small, yet noticeable, increase when the spacer is composed of $30 \mathrm{~T}(x=30)$. This number of strands is also greater than the number of streptavidin available on $\mathrm{Al} @ \mathrm{Al}_{2} \mathrm{O}_{3}$ surfaces (equal to $\sim 830 \pm 120$ proteins per 
nanoparticle, see Figure $4 \mathbf{b}$ ). We deduce that $\sim 90 \%$ of the $s s-A_{x}$ strands are directly chemisorbed on $\mathrm{Al} @ \mathrm{Al}_{2} \mathrm{O}_{3}$ nanoparticle surface, and that the remaining $\sim 10 \%$ of $s s-A_{x}$ strands are attached on streptavidin sites. Overall, the non-specific chemisorption reaction is by far the most efficient for DNA binding on oxide surfaces, despite the repulsive and steric forces induced by the negative charges of the molecular DNA strands. This result is consistent with chemisorption reaction of DNA with alumina surfaces that we reported in a previous work. ${ }^{31}$

The difference between the measured DNA surface densities of $\mathrm{Al} @ \mathrm{Al}_{2} \mathrm{O}_{3}$ and $\mathrm{CuO}$ nanoparticles is too large (three times higher) to be explained solely by an underestimation of the total surface of $\mathrm{CuO}$ nanoparticles. It suggests that DNA interacts differently on both oxide surfaces. This point is discussed in the next section regarding the hydrodynamic radii before and after DNA grafting.

\section{Characterization of hybridization efficiency.}

We quantified the hybridization efficiency, as defined by the amount of complementary DNA single-strands that are bound to nanoparticles by fluorescence intensity measurements (see the Methods section). Briefly, the complementary DNA single strands can either hybridize or simply stick on the oxide surface, typically with higher binding energy for the latter process. Then, annealing above the hybridization melting temperature releases the hybridized fluorescent DNA strands, allowing their quantification by examining the change in fluorescence before and after annealing. Such quantification is important to develop a controlled and reliable DNA-mediated $\mathrm{Al} @ \mathrm{Al}_{2} \mathrm{O}_{3}$ and $\mathrm{CuO}$ assembly process, and to provide the basis for a fundamental understanding of the assembly mechanisms. 
Single-stranded oligonucleotides with the $s s$ - $B_{x}$ "sticky-end" sequence are added to the colloidal suspensions of $\mathrm{Al} @ \mathrm{Al}_{2} \mathrm{O}_{3}$ and $\mathrm{CuO}$ nanoparticles, both previously functionalized with the complementary "sticky-end" sequence $s s-A_{x}$. After an incubation time of $8 \mathrm{~h}$, the number of $s s-B_{x}$ strands hybridized to $s s-A_{x}$ is measured; the solution is then heated at $80^{\circ} \mathrm{C}$ for $5 \mathrm{~min}$ to dehybridize $s s-B_{x}$ and the number of de-hybridized strands is measured again for normalization. This temperature is sufficient to ensure a de-hybridization of complementary strands, as demonstrated previously by studying the thermal behavior of $\mathrm{Al}-\mathrm{CuO}$ nanocomposites under 70 ${ }^{\circ} \mathrm{C},{ }^{34}$ (reported in SI Figure S3). However, this temperature is believed not to release oligonucleotides directly grafted on the nanoparticle surface, i.e. there is no disaggregation of the nanostructures. Indeed, our previous study suggested an increase of adsorbed DNA with temperature on $\mathrm{Al}_{2} \mathrm{O}_{3}$ surfaces, ${ }^{31}$ further corroborating the choice of the temperature.

As shown in Figure 5a and 5b, the hybridization efficiency is independent of the spacer length and constant at $\sim 5 \%$ and $\sim 11 \%$ for $\mathrm{CuO}$ and $\mathrm{Al} @ \mathrm{Al}_{2} \mathrm{O}_{3}$ nanoparticles, respectively. Importantly, the hybridization efficiency for each colloid corresponds exactly to the percentage of $s s-A_{x}$ attached to streptavidin sites, assuming that only one $s s-A_{x}$ is fixed on each streptavidin. Indeed, the streptavidin occupancy ratio, defined as the number of DNA strands specifically grafted by their biotin moiety per streptavidin (corresponding to the number of hybridized strands), is equal to $115 \pm 22 \%$ and $91 \pm 18 \%$ for $\mathrm{CuO}$ and $\mathrm{Al} @ \mathrm{Al}_{2} \mathrm{O}_{3}$ nanoparticles, respectively. Therefore, these hybridization efficiencies are very low, putting in question the efficiency of the self-assembly. However, the hybridization between specifically grafted complementary DNA oligonucleotides is dominant compared to non-specific interactions in the overall self-assembly process, as previously demonstrated. ${ }^{34}$ Briefly, aggregation kinetics and SEM images of the self-assembled composites obtained with or without complementary DNA strands are presented in SI Figure S7. 

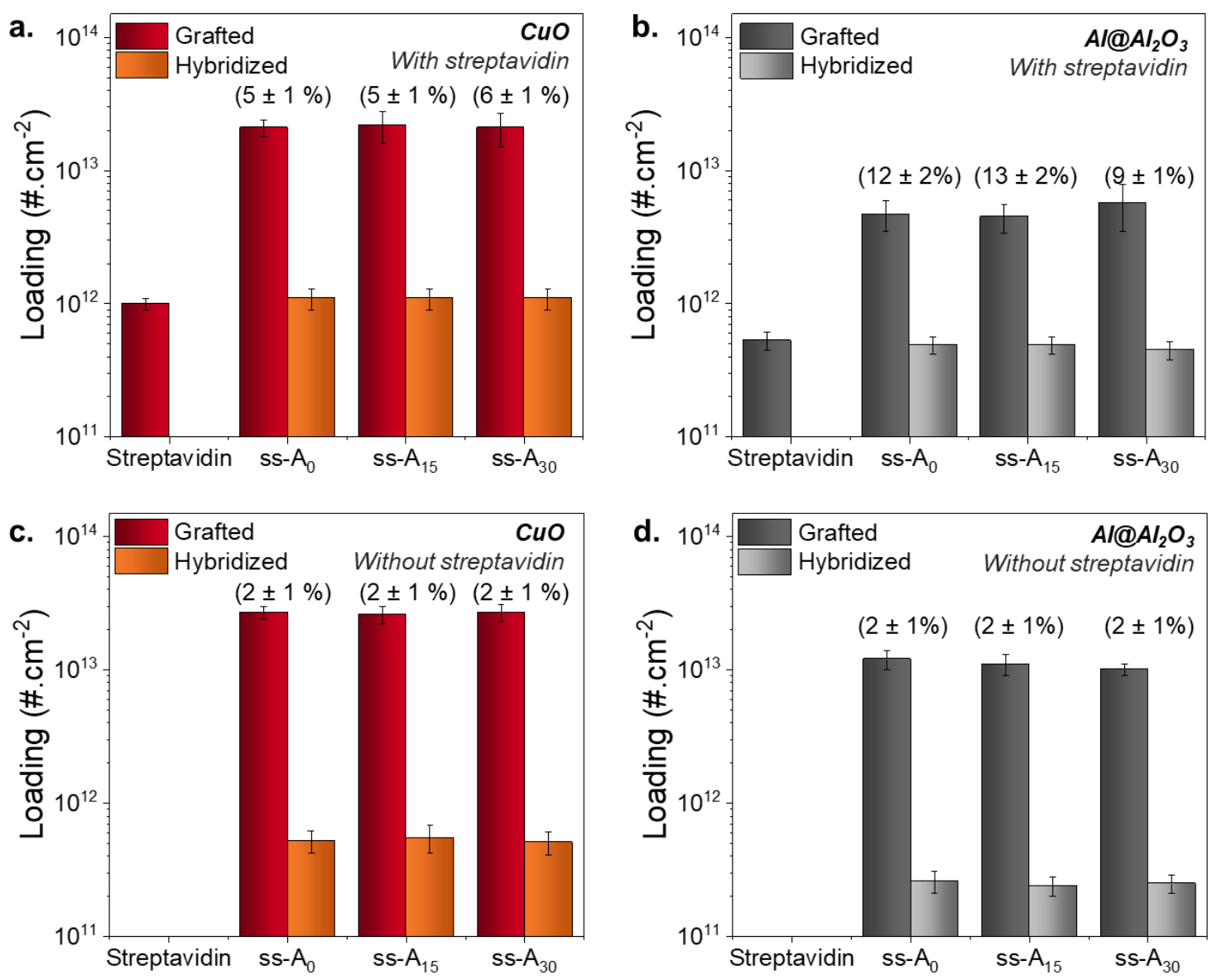

Figure 5. Summary of surface densities of $s s-D N A$ and Streptavidin and Hybridization Efficiencies for (a) $\mathrm{CuO}$ nanoparticles and (b) $\mathrm{Al} @ \mathrm{Al}_{2} \mathrm{O}_{3}$ nanoparticles, using three spacer lengths $(\mathrm{x}=0,15$ and $30 \mathrm{~T})$. Summary of surface densities of $s s-D N A$ and Hybridization Efficiencies for (c) $\mathrm{CuO}$ nanoparticles and (d) $\mathrm{Al} @ \mathrm{Al}_{2} \mathrm{O}_{3}$ nanoparticles without streptavidin coating. Colloids are prepared following the optimized protocol: the buffers contain PB $10 \mathrm{mM}$ and Tween 20 0.05\% vol:vol for Streptavidin coating and PBS 0.1X and Tween $200.05 \%$ vol:vol for DNA grafting. Incubation times are $8 \mathrm{~h}$ for streptavidin and DNA, and 5 min of sonication is performed prior to the incubation. The $\mathrm{NaCl}$ concentration is $35 \mathrm{mM}$. Rounded 
hybridization efficiencies are noted in brackets directly on the graph. Exact values are reported in SI, Table S8. Identical axes parameters are used to underline differences between nanoparticles.

The role of streptavidin coating is now assessed by comparing the hybridization efficiency with and without streptavidin molecules adsorbed on the nanoparticles (Figure 5c and 5d), using identical sequences (see Table 1). The DNA surface density and the hybridization efficiency of $s s-A_{x}$ strands directly grafted on the $\mathrm{Al} @ \mathrm{Al}_{2} \mathrm{O}_{3}$ and $\mathrm{CuO}$ nanoparticle surfaces are measured following exactly the same protocol (without the presence of streptavidin).

The results reveal that, without the streptavidin coating, $\mathrm{CuO}$ nanoparticles contain roughly three times more $s s-A_{x}$ DNA molecules on their surface than $\mathrm{Al} @ \mathrm{Al}_{2} \mathrm{O}_{3}$ nanoparticles. Despite this difference in $s s-A_{x}$ surface density, the hybridization efficiencies are comparable $(\sim 2 \pm 1 \%)$. These low hybridization efficiencies imply that the non-specific DNA strand immobilization is associated with a poor functionality of the molecules for hybridization, as discussed below. This result therefore confirms the relevance of the biotin/streptavidin functionalization strategy for oxide surfaces, which ensures the DNA functionality since the biotin/streptavidin bond leads to better hybridization efficiency.

These observations can be understood by quantifying the surface densities and the arrangement of the adsorbed DNA molecules with and without streptavidin, i.e. a well-organized standing up brush vs a chaotic intermixed strand. First, the determination of DNA footprint around nanoparticles (defined by the area occupied by one strand assuming a uniform distribution of grafted strands in a dense brush conformation) ${ }^{36}$ provides another insight into the DNA arrangement on streptavidin-free nanoparticle surfaces. On $\mathrm{CuO}$, each $s s-A_{x}$ covers 3.9, 3.7 and $2.9 \mathrm{~nm}^{2}$ for a strand length of 15,30 and 45 bases, respectively. These footprints are five times 
less than the footprint for 25 bases oligonucleotides grafted on $200 \mathrm{~nm}$ gold nanoparticles of $15 \pm$ $2 \mathrm{~nm}^{2}$ in a brush conformation. ${ }^{36}$ In contrast, on $\mathrm{Al} @ \mathrm{Al}_{2} \mathrm{O}_{3}$ nanoparticles, the footprint is closer but still smaller to that reported for gold nanoparticles of 7.1, 12.0 and $13.9 \mathrm{~nm}^{2}$ for a DNA strand of 15, 30 and 45 bases, respectively. The denser arrangement obtained for metal oxides nanoparticles, compared to that of gold nanoparticles, suggests that the conformation of DNA is not simply a brush conformation, i.e. standing-up on the surface, but a more complex arrangement where strands are probably partially laying down on the surface.

These footprints can further be analyzed using the hydrodynamic radius of nanoparticles, as inferred from Dynamic Light Scattering (DLS). Results are given in Figure 6 as a function of DNA length with or without streptavidin coating. They are compared to a theoretical value calculated by considering the DNA strand with a rod-like orientation on the surface (approximately 10 bases $/ 3 \mathrm{~nm}$ ). ${ }^{36}$ Note that the reference value also increases by $5 \mathrm{~nm}$ when there is streptavidin on the surface. ${ }^{43}$

a. Without streptavidin

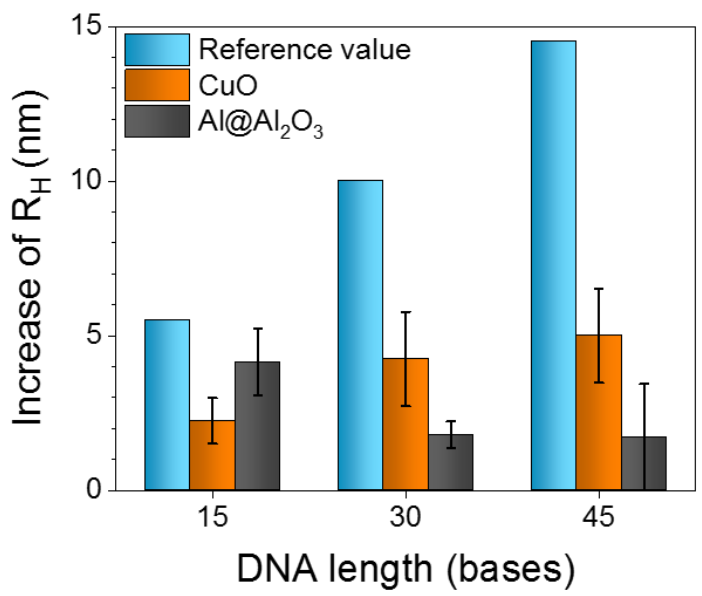

\section{b. With streptavidin}

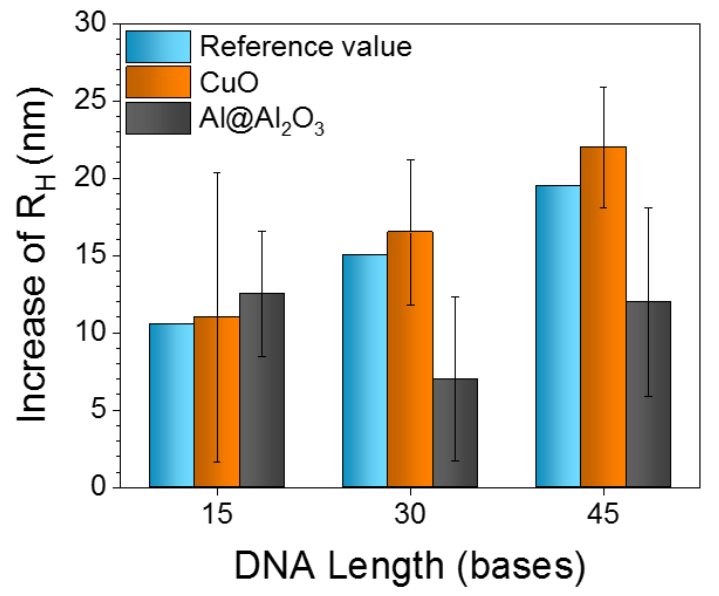

Figure 6. Increase of hydrodynamic radii of $\mathrm{Al} @ \mathrm{Al}_{2} \mathrm{O}_{3}$ and $\mathrm{CuO}$ colloidal suspensions after DNA functionalization (a) without or (b) with the streptavidin coating step, as a function of 
DNA strand length, and compared to a reference value considering a dense brush model for the conformation of grafted strands.

First, without streptavidin on the nanoparticle surfaces (Figure 6a), the radius of the $\mathrm{CuO}$ nanoparticles slightly increases by $2.3 \pm 0.8,4.3 \pm 1.5 \mathrm{~nm}$, and $5 \pm 1.5 \mathrm{~nm}$ after functionalization with 15, 30 and 45-base oligonucleotides, respectively. For all oligonucleotide lengths, the increase is lower than expected (reference values: $5.5 \mathrm{~nm}, 10 \mathrm{~nm}$ and $14.5 \mathrm{~nm}$ respectively). However, the same relationship is observed for experimental and reference values, i.e. a slight increase of the radius with the length of the oligonucleotide. These lower measured lengths suggest that DNA strands are partially folded on the surface in a dense, possibly multilayer, network, the complexity of which increases with the number of bases. In contrast, for $\mathrm{Al} @ \mathrm{Al}_{2} \mathrm{O}_{3}$ nanoparticles, the radius surprisingly decreases slightly from $4.2 \pm 1.1 \mathrm{~nm}$ to $1.7 \pm 1.7 \mathrm{~nm}$, suggesting that the degree of adsorption, and hence of spreading, increases with the length of the strand. Nevertheless, these results confirm that the "sticky-ends" of the strands are either partially or fully bound to the surface of both nanoparticles, thereby altering the efficiency of hybridization (see Figure 5).

In contrast, with streptavidin grafted on the surface (see Figure 6b), results are more consistent with brush models for both types of nanoparticles, confirming the rod-like orientation of DNA strands grafted by their biotin moiety onto the proteins. Note that the slightly lower values obtained for DNA lengths of 30 and 45 bases grafted on $\mathrm{Al} @ \mathrm{Al}_{2} \mathrm{O}_{3}$ nanoparticles $(7 \pm 5 \mathrm{~nm}$ and $12 \pm 6 \mathrm{~nm}$ compared to expected values of 15 and $20 \mathrm{~nm}$ ) could be attributed to a partial folding of strands on the surface due to the mutual attractive forces between the strands and the nanoparticle surface. Since the hybridization efficiency is not affected, it is possible that only the 
"bottom" part of the strand (i.e. the spacer part, closest to the nanoparticle) is folded on the surface.

In summary, we demonstrated that DNA exhibits multiple grafting modes on reactive oxide surfaces such as alumina and copper oxides pre-functionalized with streptavidin: (i) a major part of the DNA strands ( $\sim 90$ and 95\%) are directly chemisorbed on the surface of $\mathrm{Al} @ \mathrm{Al}_{2} \mathrm{O}_{3}$ or $\mathrm{CuO}$ nanoparticles through non-specific binding, with a higher coverage on $\mathrm{CuO}$ nanoparticles, and these molecules are predominantly lying on the surface in a disordered manner; (ii) a smaller fraction of the DNA strands is specifically grafted on streptavidin sites by their biotin moiety, and these molecules stand upright and can therefore be hybridized through their functional "sticky-end" parts. These two modes are illustrated in Figure 7. However, it appears necessary to pre-functionalize the nanoparticles surfaces to avoid non-specific interactions and to ensure a total control of the self-assembled structure, opening the door to further developments. 


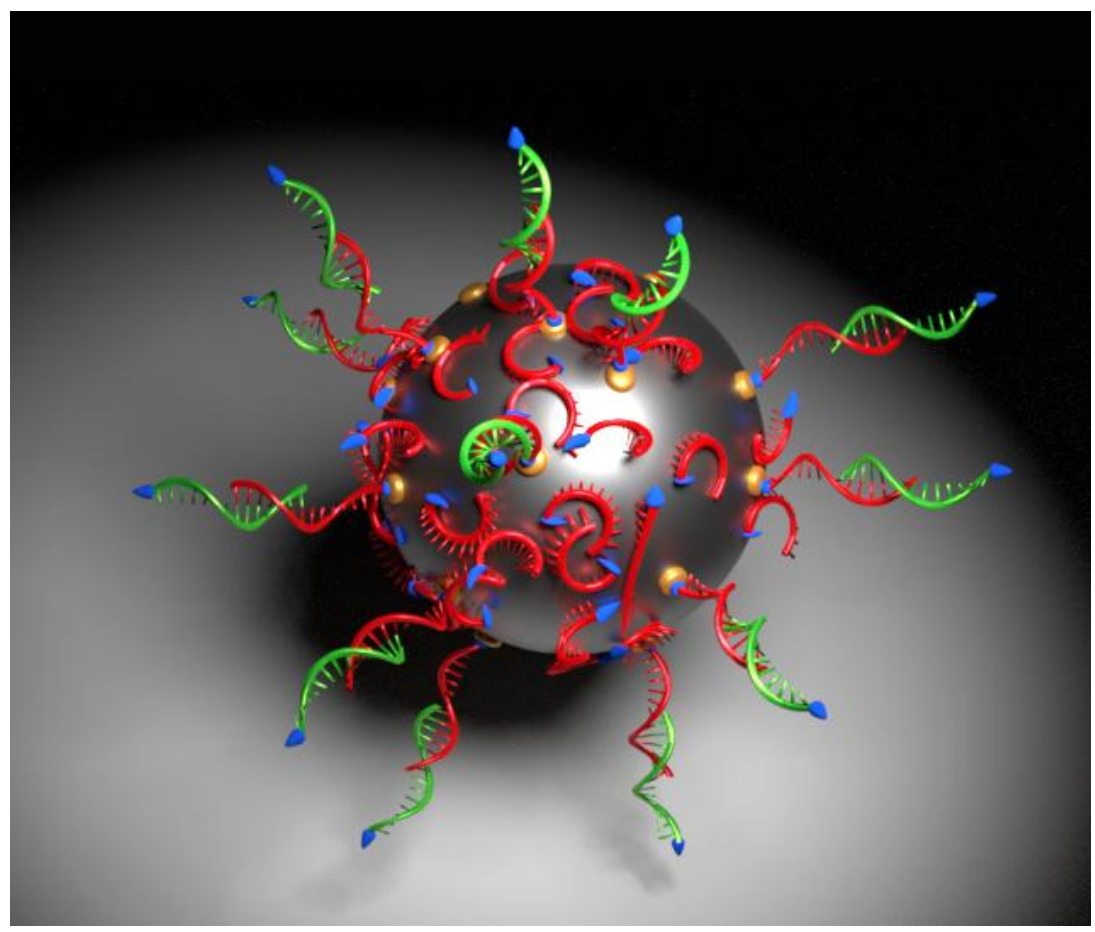

Figure 7. Schematic view of the two different biotinylated single-stranded DNA $\left(s s-A_{x}\right)$ grafting modes: (i) attached to the biotin group (red strands) via the streptavidin moiety represented in yellow. These strands are functional and can hybridize with complementary strands (green strands), (ii) higher DNA strand quantity grafted directly on the free oxide surface not being able to hybridize with their complementary green strands.

\section{SUMMARY AND CONCLUSIONS}

We described a robust and reproducible method to disperse and stabilize $\mathrm{CuO}$ and $\mathrm{Al} @ \mathrm{Al}_{2} \mathrm{O}_{3}$ nanoparticles in an aqueous solvent, and to functionalize them with streptavidin and biotinylated single-stranded DNA molecules. As presented in this paper, a careful control of the selected process parameters is required to maximize the DNA surface density. We find that (1) the $\mathrm{NaCl}$ concentration has to be in the range of $15-30 \mathrm{mM}$ to avoid irreversible nanoparticle aggregation and (2) gentle sonication during the early stage of streptavidin incubation allows for the increase of streptavidin loading by approximately $175 \%$ and $135 \%$ for the $\mathrm{CuO}$ and $\mathrm{Al} @ \mathrm{Al}_{2} \mathrm{O}_{3}$ 
nanoparticles, respectively. The DNA strand length has no noticeable impact on the DNA grafting density. We show that direct (non-specific) grafting of DNA onto $\mathrm{Al} @ \mathrm{Al}_{2} \mathrm{O}_{3}$ and $\mathrm{CuO}$ nanoparticles largely dominates the overall functionalization process; streptavidin only covers a small area of the $\mathrm{Al} @ \mathrm{Al}_{2} \mathrm{O}_{3}$ and $\mathrm{CuO}$ nanoparticles (5-10\%) but biotinylated DNA is effectively grafted at these sites, promoting a rod-like orientation. We experimentally confirm that the strong chemical affinity of DNA bases with both copper oxide and alumina surfaces leads to a lack of control of the conformation of the immobilized strands onto the oxide surfaces. The higher density of grafted oligonucleotides observed for $\mathrm{CuO}$ suggests a partially spread-out conformation compared to the completely spread-out strands on Al. Finally, we quantitatively demonstrate the crucial role of the antigen/antibody protocol to preserve the DNA ability to hybridize, doubling the hybridization efficiency. These non-specific interactions that dominate the functionalization process do not totally hinder the self-assembly process. These results suggest that $5 \%$ of hybridization efficiency (more than 500 sites per nanoparticle, largely sufficient for the number of hybridization events needed for a self-assembly) is enough to assure a DNA self-assembly. However, further developments are expected to increase the streptavidin coverage and/or to limit DNA adsorption on the surface by developing complementary surface functionalization to cover free surface. This work provides the quantitative basis to guide further developments for optimizing DNA functional grafting on complex oxide surfaces.

\section{ASSOCIATED CONTENT}

\section{Supporting Information}

Physico-chemical properties of $\mathrm{Al} @ \mathrm{Al}_{2} \mathrm{O}_{3}$ and $\mathrm{CuO}$ nanoparticles (hydrodynamic diameter, Zeta potential) after each step of the functionalization process; calculation method for the $\mathrm{Al} @ \mathrm{Al}_{2} \mathrm{O}_{3}$ 
and $\mathrm{CuO}$ nanoparticles concentrations from hydrodynamic diameter of nanoparticles measured by DLS and from $\mathrm{Al} @ \mathrm{Al}_{2} \mathrm{O}_{3}$ and $\mathrm{Cu}$ mass concentration in solution measured by AAS; effect of Phosphate Buffer and surfactant concentration on the nanoparticle concentration; repeatability of colloidal suspensions.

\section{AUTHOR INFORMATION}

\section{Corresponding Author}

*Email: rossi@laas.fr

\section{Notes}

\section{Conflict-of-Interest Disclosure}

The authors declare no competing financial support.

\section{Funding Sources}

This study is supported by IDEX - University of Toulouse grant (ref. 138241) and French National Defense Agency.

\section{ACKNOWLEDGMENT}

The authors would like to thank Charline Blatché for fluorescence measurements as well as Sylviane Baster from LAAS-CNRS and Carole Causserand from Géoscience Environnement Toulouse for the $\mathrm{Cu}$ and $\mathrm{Al}$ quantifications.

\section{REFERENCES}

1. $\quad$ Alivisatos, A. P.; Johnsson, K. P.; Peng, X.; Wilson, T. E.; Loweth, C. J.; Bruchez, M. P.; Schultz, P. G. Organization of 'Nanocrystal Molecules' Using DNA. Nature 1996, 382, $609-611$. 
2. Mirkin, C. A.; Letsinger, R. L.; Mucic, R. C.; Storhoff, J. J. A DNA-Based Method for Rationally Assembling Nanoparticles into Macroscopic Materials. Nature 1996, 382, $607-609$.

3. Macfarlane, R. J.; Jones, M. R.; Lee, B.; Auyeung, E.; Mirkin, C. A. Topotactic Interconversion of Nanoparticle Superlattices. Science 2013, 341, 1222-1225.

4. Auyeung, E.; Li, T. I. N. G.; Senesi, A. J.; Schmucker, A. L.; Pals, B. C.; de la Cruz, M. O.; Mirkin, C. A. DNA-Mediated Nanoparticle Crystallization into Wulff Polyhedra. Nature 2014, 505, 73-77.

5. Lermusiaux, L.; Bidault, S. Increasing the Morphological Stability of DNA-Templated Nanostructures with Surface Hydrophobicity. Small (Weinheim an der Bergstrasse, Germany) 2015, 11, 5696-5704.

6. Vo, T.; Venkatasubramanian, V.; Kumar, S.; Srinivasan, B.; Pal, S.; Zhang, Y.; Gang, O. Stoichiometric Control of DNA-Grafted Colloid Self-Assembly. Proc. Natl. Acad. Sci. U. S. A. 2015, 112, 4982-4987.

7. O'Brien, M. N.; Lin, H. X.; Girard, M.; de la Cruz, M.; Mirkin, C. A. Programming Colloidal Crystal Habit with Anisotropic Nanoparticle Building Blocks and DNA Bonds. J. Am. Chem. Soc. 2016, 138, 14562-14565.

8. Liu, J.; Lu, Y. Fast Colorimetric Sensing of Adenosine and Cocaine Based on a General Sensor Design Involving Aptamers and Nanoparticles. Angew. Chem., Int. Ed. 2006, 45, $90-94$. 
9. Lee, J. S.; Ulmann, P. A.; Han, M. S.; Mirkin, C. A. A DNA-Gold Nanoparticle-Based Colorimetric Competition Assay for the Detection of Cysteine. Nano Lett. 2008, 8, 529533.

10. Liu B, Liu J. DNA Adsorption by Magnetic Iron Oxide Nanoparticles and its Application for Arsenate Detection. Chem. Commun. 2014, 50, 8568-70.

11. Scott, A. W.; Garimella, V.; Calabrese, C. M.; Mirkin, C. A. Universal Biotin-PegLinked Gold Nanoparticle Probes for the Simultaneous Detection of Nucleic Acids and Proteins. Bioconjugate Chem. 2016. DOI: 10.1021/acs.bioconjchem.6b00529.

12. Chou, L. Y. T.; Zagorovsky, K.; Chan, W. C. W. DNA Assembly of Nanoparticle Superstructures for Controlled Biological Delivery and Elimination. Nat. Nanotechnol. 2014, $9,148-155$.

13. de Ávila, B. E.; Martín, A. D.; Soto, F.; Lopez-Ramirez, M. A.; Campuzano, S.; Vásquez-Machado, G. M.; Gao, W.; Zhang, L.; Wang, J. Single Cell Real-Time miRNAs Sensing Based on Nanomotors. ACS Nano 2015, 9, 6756-6764.

14. Fan, J. A.; He, Y.; Bao, K.; Wu, C.; Bao, J.; Schade, N. B.; Manoharan, V. N.; Shvets, G.; Nordlander, P.; Liu, D. R.; Capasso, F. DNA-Enabled Self-Assembly of Plasmonic Nanoclusters. Nano Lett. 2011, 11, 4859-4864.

15. Busson, M. P.; Rolly, B.; Stout, B.; Bonod, N.; Bidault, S. Accelerated Single Photon Emission from Dye Molecule-Driven Nanoantennas Assembled on DNA. Nat. Commun. 2012, 3, 962. 
16. Tan, L. H.; Xing, H.; Chen, H.; Lu, Y. Facile and Efficient Preparation of Anisotropic DNA-Functionalized Gold Nanoparticles and their Regioselective Assembly. J. Am. Chem. Soc. 2013, 135, 17675-17678.

17. Li, N.; Tittl, A.; Yue, S.; Giessen, H.; Song, C.; Ding, B.; Liu, N. DNA-Assembled Bimetallic Plasmonic Nanosensors. Light: Sci. Appl. 2014, 3, e226.

18. Lee, S. E.; Chen, Q.; Bhat, R.; Petkiewicz, S.; Smith, J. M.; Ferry, V. E.; Correia, A. L.; Alivisatos, A. P.; Bissell, M. J. Reversible Aptamer-Au Plasmon Rulers for Secreted Single Molecules. Nano Lett. 2015, 15, 4564-4570.

19. Ross, M. B.; Bourgeois, M. R.; Mirkin, C. A.; Schatz, G. C. Magneto-Optical Response of Cobalt Interacting with Plasmonic Nanoparticle Superlattices. J. Phys. Chem. Lett. 2016, 7, 4732-4738.

20. Auyeung, E.; Morris, W.; Mondloch, J. E.; Hupp, J. T.; Farha, O. K.; Mirkin, C. A. Controlling Structure and Porosity in Catalytic Nanoparticle Superlattices with DNA. J. Am. Chem. Soc. 2015, 137, 1658-1662.

21. Mirkin, C. A. Programming the Assembly of Two- and Three-Dimensional Architectures with DNA and Nanoscale Inorganic Building Blocks. Inorg. Chem. 2000, 39, 2258-2272.

22. Park, S.-J.; Lazarides, A. A.; Storhoff, J. J.; Pesce, L.; Mirkin, C. A. The Structural Characterization of Oligonucleotide-Modified Gold Nanoparticle Networks Formed by DNA Hybridization. J. Phys. Chem. B 2004, 108, 12375-12380. 
23. Nykypanchuk, D.; Maye, M. M.; van der Lelie, D.; Gang, O. DNA-Guided Crystallization of Colloidal Nanoparticles. Nature 2008, 451, 549-552.

24. Cobbe, S.; Connolly, S.; Ryan, D.; Nagle, L.; Eritja, R.; Fitzmaurice, D. DNA-Controlled Assembly of Protein-Modified Gold Nanocrystals. J. Phys. Chem. B 2003, 107, 470-477.

25. Castelino, K.; Kannan, B.; Majumdar, A. Characterization of Grafting Density and Binding Efficiency of DNA and Proteins on Gold Surfaces. Langmuir 2005, 21, 19561961.

26. Zhang, Y.; Lu, F.; Yager, K. G.; van der Lelie, D.; Gang, O. A General Strategy for the DNA-Mediated Self-Assembly of Functional Nanoparticles into Heterogeneous Systems. Nat. Nanotechnol. 2013, 8, 865-872.

27. Lu, F.; Gang, O. In 3D DNA Nanostructure; Ke, Y., Wang, P., Eds.; Springer: New York, 2017; pp 99-107.

28. Séverac, F.; Alphonse, P.; Estève, A.; Bancaud, A.; Rossi, C. High-Energy Al/CuO Nanocomposites Obtained by DNA-Directed Assembly. Adv. Funct. Mater. 2012, 22, $323-329$.

29. Aumann CE, Skofronick GL, Martin JA. Oxidation behavior of aluminum nanopowders. J. Vac. Sci. Technol. B 1995, 13, 1178-83.

30. Weismiller MR, Malchi JY, Lee JG, Yetter RA, Foley TJ. Effects of fuel and oxidizer particle dimensions on the propagation of aluminum containing thermites. Proc. Combust. Inst. 2011, 33, 1989-96. 
31. Calais, T.; Playe, B.; Ducéré, J.-M.; Veyan, J.-F.; Rupich, S.; Hemeryck, A.; Djafari Rouhani, M.; Rossi, C.; Chabal, Y. J.; Estève, A. Role of Alumina Coatings for Selective and Controlled Bonding of DNA on Technologically Relevant Oxide Surfaces. J. Phys. Chem. C 2015, 119, 23527-23543.

32. Pautler R, Kelly EY, Huang PJ, Cao J, Liu B, Liu J. Attaching DNA to Nanoceria: Regulating Oxidase Activity and Fluorescence Quenching. ACS Appl. Mater. Interfaces 2013, 5, 6820-5.

33. Zhang X, Wang F, Liu B, Kelly EY, Servos MR, Liu J. Adsorption of DNA Oligonucleotides by Titanium Dioxide Nanoparticles. Langmuir 2014, 30, 839-45.

34. Calais, T. O.; Baijot, V.; Rouhani, M. D.; Gauchard, D.; Chabal, Y. J.; Rossi, C.; Esteve, A. General Strategy for the Design of DNA Coding Sequences Applied to Nanoparticle Assembly. Langmuir 2016, 32, 9676-9686.

35. Taton, T. A.; Mirkin, C. A.; Letsinger, R. L. Scanometric DNA Array Detection with Nanoparticle Probes. Science 2000, 289, 1757-1760.

36. Hill, H. D.; Millstone, J. E.; Banholzer, M. J.; Mirkin, C. A. The Role Radius of Curvature Plays in Thiolated Oligonucleotide Loading on Gold Nanoparticles. ACS Nano 2009, 3, 418-424.

37. Hurst, S. J.; Lytton-Jean, A. K.; Mirkin, C. A. Maximizing DNA Loading on a Range of Gold Nanoparticle Sizes. Anal. Chem. 2006, 78, 8313-8318. 
38. Blythe, K. L.; Titus, E. J.; Willets, K. A. Triplet-State-Mediated Super-Resolution Imaging of Fluorophore-Labeled Gold Nanorods. Chemphyschem 2014, 15, 784-793.

39. Arulmurugan, R.; Jeyadevan, B.; Vaidyanathan, G.; Sendhilnathan, S. Effect of Zinc substitution on Co-Zn and Mn-Zn ferrite nanoparticles. J. Magn. Magn. Mater. 2005, $288,470-477$.

40. Yang, X.; Zhang, X.; Ma, Y.; Huang, Y.; Wang, Y.; Chen, Y. Superparamagnetic graphene oxide $-\mathrm{Fe} 3 \mathrm{O} 4$ nanoparticles hybrid for controlled targeted drug carriers. J. Mater. Chem. 2009, 19, 2710-2714.

41. Ghanemi, K.; Nikpour, Y.; Omidvar, O.; Maryamabadi, A. Sulfur-nanoparticle-based method for separation and preconcentration of some heavy metals in marine samples prior to flame atomic absorption spectrometry determination. Talanta 2011, 85, 763-769.

42. Liu B, Liu J. DNA Adsorption by Indium Tin Oxide Nanoparticles. Langmuir 2014, 31, $371-7$.

43. Weber, P. C.; Ohlendorf, D. H.; Wendoloski, J. J.; Salemme, F. R. Structural Origins of High-Affinity Biotin Binding to Streptavidin. Science 1989, 243, 85.

44. Wilchek M, Bayer EA. [3] Applications of Avidin-Biotin technology: Literature survey. In Methods in Enzymology, M.W. and E.A. Bayer, ed. (Academic Press) 1990, pp. 1445.

45. Hagyard, T.; Williams, J. R. Potential of Aluminium in Aqueous Chloride Solutions. Part 1. Trans. Faraday Soc. 1961, 57, 2288-2294. 
TOC Graphic

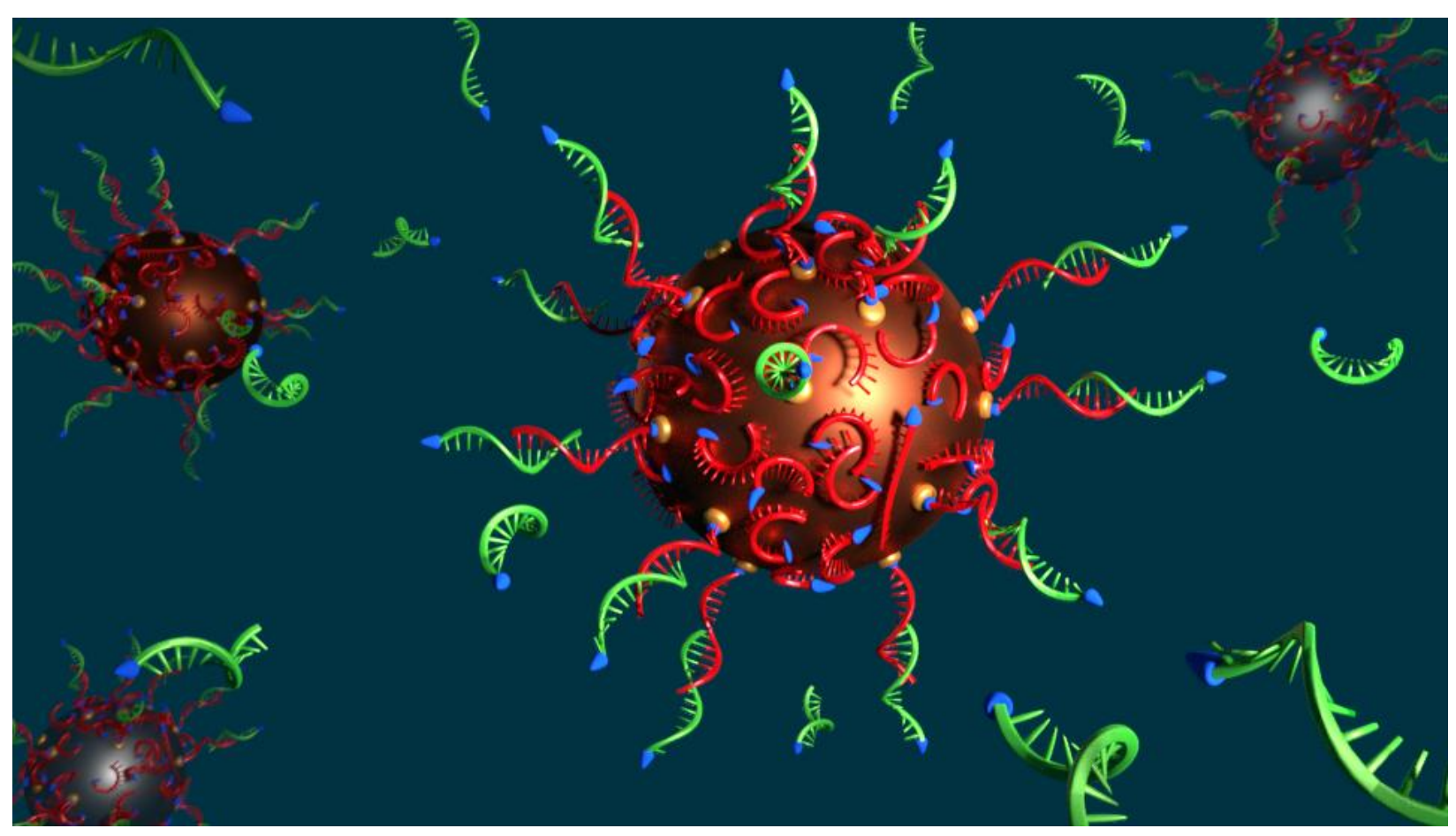

